\title{
STRATEGI TUMBUH DAN BERSAING DI INDUSTRI ASURANSI (STUDI KASUS PADA BPJS KETENAGAKERJAAN PEKANBARU)
}

\author{
Nofrizal \\ Email: Nofrizalfe@unilak.ac.id \\ Lecturerof faculty Economic University Lancang Kuning Pekanbaru
}

\begin{abstract}
Background this research began by observing growth and rising insurance company in Pekanbaru city with many company insurance had been built in Pekanbaru city since 2014, therefore rivalry can't avoid and each company also create and arrange tactic and strategy,in order to be winner from this competition. BPJS Ketenagakerjaan is new entry from in insurance industry in Pekanbaru city and BJPS Ketenagakerjaan owned by government Indonesia. Aim this research to arrange and determine how BPJS Ketenagakerjaan growth and compete in insurance industry Pekanbaru city. This research use descriptive method with several step to create strategy there are Five Force Porter, IFA, EFA, Matric GE, SWOT-8K,Matric TWOS and Matric QSPM. Result this research showed the strategy Position of BPJS Ketenagakerjaan in quadrant IB (Growth) and BPJS Ketenagakerjaan can use for growth and compete using Competitive Strategy and Growth strategy
\end{abstract}

Keywords: Competitive Strategy, Insurance, SWOT-8K

\begin{abstract}
Abstrak: Latar belakang penelitian ini dimulai oleh observasi dari pertumbuhaan dan peningkatan jumlah asuransi di kota Pekanbaru semenjak 2014, oleh karena itu persaingan tidak dapat dihindari dan masing-masing perusahaan juga membuat dan menyusun strategi dan taktik agar dapat menjadi pemenang dari persaingan ini. BPJS Ketenagakerjaan adalah pendatang baru didalam industry asuransi di Kota Pekanbaru dan BPJS Ketenagakerjaan dimiliki oleh pemerintah Indonesia. Tujuan dari penelitian ini untuk menyusun dan menentukan bagaimana BPJS Ketenagakerjaan tumbuh dan bersaing di industry asuransi Kota Pekanbaru. Penelitian ini menggunakan metode diskriptif dengan beberapa tahapan untuk membuat strategi yaitu lima kekuatan porter, IFA,EFA, Matric GE, SWOT-8K, Marik TWOS and Matrik QSPM. Hasil dari penelitian ini menunjukan posisi strategi dari BPJS Ketenagakerjaan berada di kuadran IB (Tumbuh) dan BPJS Ketenagakerjaan dapat menggunakan untuk tumbuh dan bersaing dengan mengunkan strategi bersaing dan strategi pertumbuhan
\end{abstract}

Kata Kunci: Strategi Bersaing, Asuransi, SWOT-8K

\section{LATAR BELAKANG}

Industri asuransi saat ini tidak lepas dari persaingan untuk menangkap peluang yang semakin terbuka lebar di kota pekanbaru hal ini dapat kita lihat dari semakin banyaknya tumbuh dan berdirinya perusahaan-perusahaan asuransi di pekanbaru baik dari asuransi bersekala nasional maupun global dengan jumlah lebih dari 40 perusahaan asuransi yang tersebar di seluruh Kota Pekanbaru. Dengan jumlah perusahaan asuransi tersebut maka masing-masing perusahaan asuransi tersebut berusaha untuk membuat strategi-strategi dan taktik. (Porter, 2011)menyatakan strategi adalah melakukan aktivitas yang berbeda dengan pesaing atau aktivitas yang tidak jauh berbeda dengan pesaing namun cara yang berbeda. BPJS Ketenagakerjaan didirikan sejak 1 juli 2014 yang salah satu wujud tanggung jawab dan kewajiban Negara untuk memberikan perlindungan sosial ekonomi kepada masyarakat. Sesuai dengan kondisi kemampuan keuangan Negara. Indonesia seperti halnya negara berkembang lainnya, mengembangkan program jaminan sosial 
berdasarkan funded social security, yaitu jaminan sosial yang didanai oleh peserta dan masih terbatas pada masyarakat pekerja di sektor formal(BPJS Ketenagakerjaan, 2015). Selama BPJS Ketenagakerjaan berdiri beberapa strategi telah diimplementasikan untuk dapat bersaing diindustri ini seperti menggunakan strategy horizontal growth dengan membuka cabang di seluruh Indonesia, melakukan strategy penetrasi pasar dan pengembangan produk dengan menawarkan produk-produknya ke masyarakat melalui media elektronoik dan cetak.

Sementara itu pesaing yang sudah lama beridiri sudah melakukan beberapa strategi salah satunya adalah yang dilakukan oleh PT. Prudential Life insurance Indonesiamenggunakan strategi pengembangan pasar dan penetrasi pasar dengan membuka cabang kelima (Elyati Henny, 2012)Prudential juga menawarkan produk-produk yang beragam yang sudah unit link salah satunyaPRUlink\&PRUmychild. Sedangkan dari sumber daya manusia Menurut Rinaldi Mudahar kepada Riau Pos menjelaskan saat ini jumlah agen Prudential se-Provinsi Riau lebih dari 3.500 yang memiliki lisensi agency force dan di Indonesia lebih dari 180 agen yang berlisensi keagenan yang dikeluarkan AAJI.

Sedangkan PT Manulife juga menyusun strategi penetrasi pasar dan pengembangan produk yaitu mengelurkan produk-produk menarik seperti jaminan hari tua (pensiun) yaitu RetireLink (RL) yangmerupakan program investasi yang dirancang khusus untuk merencanakan dan mengelola investasi dana pensiun agar tersedia kesinambungan penghasilan yang optimal pada usia pensiun. RetireLink memenuhi kebutuhan di masa pensiun melalui pengambilan dana yang diinvestasikan secara terjadwal pada saat Anda berusia 55, 60, 65, 70 dan 75 tahun (Swaonline, 2013).

Berdasarkan penjelasan diatasmaka BPJS Ketenagakerjan sebagai perusahaan baru di kota Pekanbaru apakah mereka dapat tumbuh dan bersaing dan menciptakan keunggulan bersaing dengan perusahaan-perusahaan asuransi yang sudah lama berdiri di kota Pekanbarudengan keadaan perusahaanya sekarang? Dan bagaimana strategi yang tepat untuk dapat tumbuh dan bersaing di industry asuransi kota Pekanbaru?

Menurut (David, 2014), (Safiullin, Samigullin, \& Safiullin, 2013), (Porter, 2011)menyatakan strategi memungkinkan organisasi untuk memperoleh keunggulan kompetitif dari tiga landasan yang berbeda yaitu: kepemimpinan biaya (cost leadership) diferensiasi (differentation) dan fokus (focus).

Oleh karena itu perencanaan strategis penting untuk memperoleh keunggulan bersaing dan memiliki produk yang sesuai dengan keinginan konsumen dengan dukungan yang optimal dari sumber daya yang ada(Sabol, Šander, \& Fučkan, 2013)which in turn creates value both for the firm and its environment. The appropriate use of specific business strategies highly depends on the phase of the life cycle of the industry in which the firm and/or its parts operate. The purpose of the paper is to understand the significance of the concept of industry life cycle and explore the implications on the process of designing business strategies. The authors familiarise the readers with the most important research that has contributed to the development of business strategies fitted to each phase of the life cycle of an industry. The paper concludes with the notion that business strategies of firms vary depending on the corresponding stage of the industry life cycle, where each phase inherently requires a different, innovative business strategy. Therefore, the main precondition of sustainable development of a strategic business unit and/ or firm is the willingness and capability of management to accept new knowledge about the interdependence between business goals and interdisciplinary knowledge required to achieve them. Menurut (Morgan, 2012) ada 11 strategi untuk keunggulan kompetitif yaitu: (1) Strategi Kepemimpinan biaya (2) Strategi Deferensiasi (3) Strategi fokus pasar (4) Strategi tumbuh (5) Strategi Aliansi (6) Strategi Inovasi (7) Strategi operasi efektif 
(8) Strategi fokus konsumen (9) Strategi waktu (10) strategi mengunci konsumen atau pemasok (11) Strategi meningkatkan biaya perubahan.

Strategi bersaing juga berhubungan dengan karakter dan persaingan didalam dunia industri baik produk/jasa tidak akan pernah sama satu dengan yang lainya. Alat yang paling sering digunakan dan lazim digunakan untuk menganalisa peta persaingan di dunia industry adalah five forces model of competition (Lima kekuatan porter dalam bersaing) yang di populerkan oleh porter (Dobbs, 2014), (Lee, Kim, dan Park, 2012)however, it has attracted less attention from both academic researchers and practicing managers. This is due to its innate weakness, difficulty in operationalization. The vital requisites for operationalizing the five forces model are to deal with it as a complex system composed of interrelated forces and their sub-forces, and to prioritize them with consideration of their interdependency. The tenet of this study is the requisites can be achieved through the analytic network process (ANP yaitu (1)persaingan dalam industri (Hunt \& Hunt, 2014) intensitas pesaing dengan industri yang sama di pengaruhi oleh Jumlah Perusahan, Rata-Rata Pertumbuhan, Karakteristik Produk/Jasa, Jumlah Biaya Tetap, Kapasitas, Tingkat Dalam Keluar Dari Industri Dan Diversifikasi Antar Perusahaan (2) Ancaman Pendatang baru (Wheelen. Thomas L, 2016) beberapa batasaan bagi pendatang baru diantaranya Skala Ekonomi, Differesiansi Produk,Modal yang dibutuhkan, Akses Pemasok, Akses Distribusi dan Peraturan Pemerintah. (3)Produk penganti (Nofrizal , 2016) produk atau barang penganti dapat membatasi pendapatan dari sebuah industri dengan menetapkan batasan harga (Maksimal\&Minimal) yang harus di patuhi. (4)Pemasok dapat menggunakan kekuatan tawar-menawar terhadap pembeli dalam industri dengan cara menaikan harga atau menurunkan kualitas produk atau jasa yang dibeli (Ang, 2014). (5) Daya tawar pembeli pada industri berperan dalam menekan harga untuk turun, serta memberikan penawaran dalam peningkatan kualitas ataupun layanaan lebih (Mirzakhani, Parsaamal, dan Golzar, 2014).

Analisis SWOT sudah lama ditawarkan oleh Harvard Business School sebagai alat untuk menyusun perencanaan strategi (Jeyaraj, Muralidharan, Senthilvelan, \& Deshmukh, 2012),(Mirzakhani dkk., 2014),(Tewari, 2016). SWOT dapat memutuskan sebuah pondasi yang sempurna untuk menyusun formulasi strategi(Sevkli dkk., 2012). Setiap keputusan yang di ambil oleh organisasi dibuat beberapa derajat berdasarkan faktor internal dan eksternal (Ayub, Razzaq, Aslam, \& Iftekhar, 2013), (Wheelen Thomas L. , Hunger J.David, 2014)lingkungan eksternal yang terdiri dari analisis dari peluang dan ancaman didalam lingkungan internal unit bisnis dikomendasikan dengan lingkungan kekuatan dan kelemahan internal unit bisnis (Muhammad, 2013). Sedangkan SWOT-8K akan membantu mengidentifikasi informasi yang dapa digunakan untuk mencapai tujuan perusahaan atau mengidentifikasi hasil yang diinginkan sesuai dengan kuadrannya yang terdiri dari 8 kuadran (Muhammad, 2013). Sedangkan matrik QSPM adalah alat yang berguna bagi para penyusun strategi untuk mengevaluasi berbagai strategi alternatif secara obyektif(Gupta, 2015)(Shiehbeiki, Abbaspour, \& Monavari, 2014)(Mirzakhani dkk., 2014). Evaluasi perlu dilakukan untuk mengetahui strategi yang masih dapat bersaing dalam pasar(Saputro, Hidayat, \& Yulianto, 2016), (Mirzakhani dkk., 2014)

\section{METODE}

Penelitian ini menggunakan metode deskriptif bertujuan untuk menemukan pola hubungan yang bersifat interaktif, menggambarkan realitas yang kompleks, serta untuk memperoleh pemahaman makna dan menemukan teori Dobbs, 2014 dalam Saputro dkk., 2016. Tahapan dalam penyusunan strategi ini berdasarkan metode yang disampikan oleh (Hunger dan david, 2013), (Bull, dkk., 2016) yaitu menentukan faktor-faktor dari ekternal 
dan internal setelah itu memasukan ke matrik IFA dan EFA setelah itu masuk ketahapan matrik GE, selanjutnya untuk menentukan posisi strategi digunakan Matrik SWOT-8K, selanjutnya masuk ke matrik IE, selanjutnya masuk Matik TWOS untuk memformulasi strategi (Bell \& Rochford, 2016)1990 tahapan terakhir adalah menentukan strategi alternatif yang paling tepat dengan menggunakan matrik QSPM.
Objek dari penelitian ini adalah seluruh cabang BPJS Ketenagakerjaan kota Pekanbaru dengan teknik pengumpulan data berupa wawancara dengan kepala cabang dan unit manajer, observasi, dan studi pustakaserta sumber daya yang digunakan berasal dari data primer dan sekunder. Untuk model desain Penelitian seperti gambar 1 .

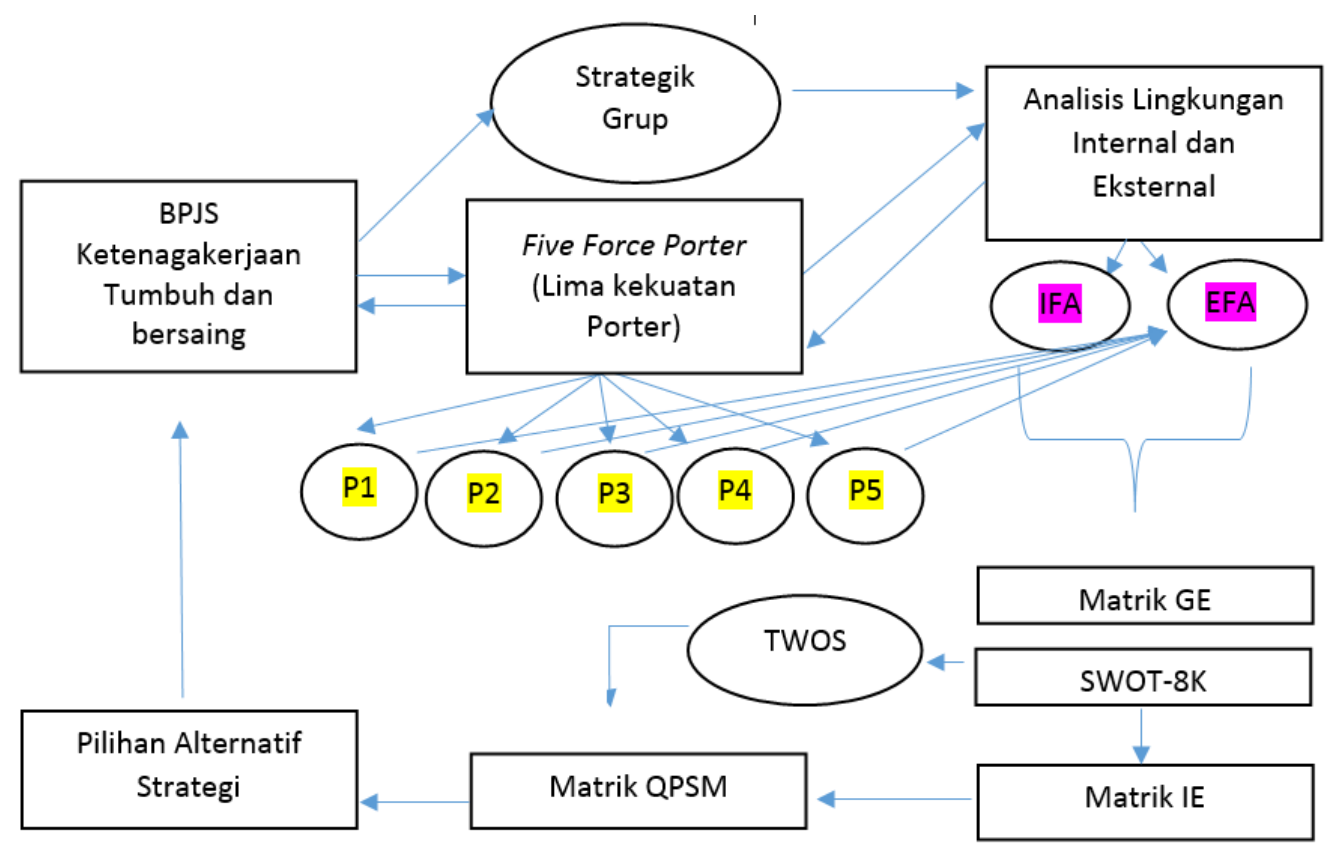

Gambar 1. Model Desain Penelitiancv

\section{HASIL}

Berdasarkan hasil pembahasan yang dilakukan ditemukan bahwa posisi strategi dari BPJS Ketenagakerjaan kota Pekanbaru dengan menggunakan Five Force Porter, IFA,EFA, Matrik GE, SWOT -8K, Matrik TWOS, dan Matrik QSPM berada pada posisi kuadran IB tumbuh stabil(Growth Stabilization). Iniberarti BPJS Ketenagakerjan Kota Pekanbaru dapat menggunakan banyak strategi untuk tumbuh dan bersaing. Sedangkan untuk strategi untuk tumbuh dan bersaing BPJS dapat mengunakan strategi tumbuh dengan pertumbuhan horizontal seperti menambah cabang baru, melakukan penetrasi pasar seperti menambah kapasitas layanan melalui media internet seperti app store dan website serta media sosial ditambah dengan menggunakan strategi Competitive strategiyaitu pemerintah harus membuat kebijakan yang menguntungkan BPJS Ketenagakerjaan.

\section{PEMBAHASAN}

Pada bagian ini (pembahasan) peneliti akan memberikan ulasan dari hasi penelitian yang diperoleh sumber data dan infromasi yang didapatkan berasal dari wawancara, observasi, studi pustaka serta beberapa penelitian sebelumnya tentang strategi tumbuh dan bersaing.

\section{Lima Kekuatan Porter dan Strategik Grup}

Dari kelima kekuatan Porter ditemukan bahwa hasil analisis menunjukan BPJS 
ketenagakerjaan kota Pekanbaru memiliki pengaruh lemah terhadapfive force porter (lima kekuatan porter) hanya pada item persaingan dalam industri dan produk penganti memiliki pengaruh sedang hal ini disebabkan jumlah pesaing di industry asuransi kota pekanbaru cukup banyak sehingga mengakibatakan produk penganti memiliki pengaruh terhadap BPJS Ketenagakerjaan. Untuk lebih jelas lihat gambar 2 dibawah ini.

Tabel 1. Five Force Porter

\begin{tabular}{|c|c|c|c|c|}
\hline \multirow[t]{2}{*}{ No } & \multirow{2}{*}{$\begin{array}{c}\text { Five Forces } \\
\text { Porter (Lima } \\
\text { Kekuatan Porter) }\end{array}$} & \multicolumn{3}{|c|}{$\begin{array}{l}\text { Tingat Pengaruh } \\
\text { Terhadap BPJS } \\
\text { Ketenagakerjaan }\end{array}$} \\
\hline & & Lemah & Sedang & Kuat \\
\hline 1 & $\begin{array}{l}\text { Persaingan Dalam } \\
\text { Industri }\end{array}$ & & $\mathrm{v}$ & \\
\hline 2 & $\begin{array}{l}\text { Kekuatan Tawar } \\
\text { Pembeli }\end{array}$ & $\mathrm{v}$ & & \\
\hline 3 & Kekuatan Pemasok & $\mathrm{V}$ & & \\
\hline 4 & Pendatang Baru & $\mathrm{v}$ & & \\
\hline 5 & Produk Penganti & & $\mathrm{v}$ & \\
\hline
\end{tabular}

Sedangkan pada analisis strategik grup ditemukan bahwa posisi BPJS Ketenagakerjaan berada pada posisi low (rendah) berada satu kolom dengan taspen ini disebabkan karenan BPJS Ketenagakerjaan masih baru sebagai pemain diindustri asuransi di Indonesia khususnya kota Pekanbaru. Untuk posisi paling tinggi di tempati oleh Manulife dan Prudential lihat gambar 2 dibawah ini.

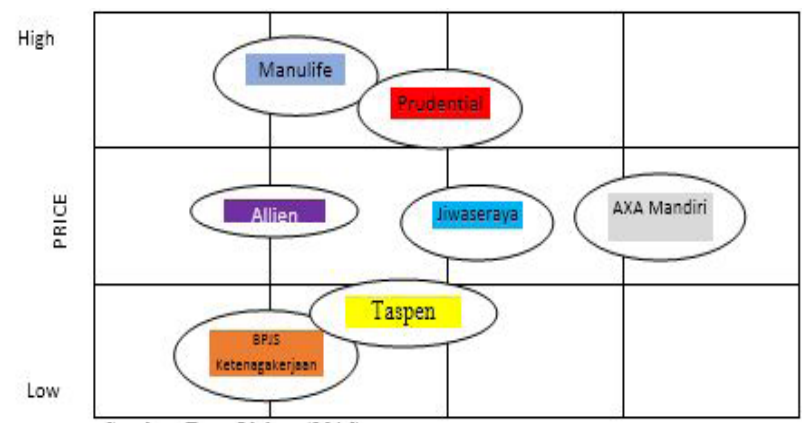

Gambar 2. Strategik Group

Setelah mengetahui dari analisis lima kekuatan porter (five force Porter) dan strategi grup diatas selanjutkan akan dilakukan analisis untuk melihat masing-masing bobot dengan mengunakan analisis EFA (EksternalFaktorAnalisis) EFA ini digunakan untuk menentukan nilai bobot dari BPJS ketenagakerjaan yang berasal dari eksternal perusahaan (BPJS Ketenagakerjaan) untuk lebih lihat tabel 2 dibawah ini.

Tabel 2.Eksternal Faktor Analisis: BPJS Ketenagakerjaan

\begin{tabular}{|c|c|c|c|c|}
\hline $\begin{array}{c}\text { Exsternal } \\
\text { Factor } \\
\text { (Faktor } \\
\text { Eksternal) }\end{array}$ & $\begin{array}{l}\text { Weight } \\
\text { (Bobot) }\end{array}$ & $\begin{array}{l}\text { Rating } \\
\text { (Nilai) }\end{array}$ & $\begin{array}{l}\text { Weight } \\
\text { Score } \\
\text { (Nilai } \\
\text { tertimbang) }\end{array}$ & Keterangan \\
\hline \multicolumn{5}{|l|}{$\begin{array}{l}\text { Peluang } \\
\text { (Opportunity) }\end{array}$} \\
\hline Demografi & 0,10 & 4 & 0,40 & $\begin{array}{l}\text { Jumlah penduduk } \\
\text { Kecamatan Tampan } \\
\text { mencapai } 220.208 \text { jiwa } \\
\text { dan terus meningkat setiap } \\
\text { tahun }\end{array}$ \\
\hline $\begin{array}{l}\text { Perkembangan } \\
\text { Ekonomi }\end{array}$ & 0,19 & 5 & 0,95 & $\begin{array}{l}\text { Produk Domestik } \\
\text { Regional Bruto. (PDRB) } \\
\text { atas dasar harga berlaku } \\
\text { triwulan III/2016 } \\
\text { mencapai Rp172,82 triliun } \\
\text { tumbuh } 3.40 \text { persen. }\end{array}$ \\
\hline
\end{tabular}




\begin{tabular}{|c|c|c|c|c|}
\hline $\begin{array}{c}\text { Exsternal } \\
\text { Factor } \\
\text { (Faktor } \\
\text { Eksternal) }\end{array}$ & $\begin{array}{l}\text { Weight } \\
\text { (Bobot) }\end{array}$ & $\begin{array}{l}\text { Rating } \\
\text { (Nilai) }\end{array}$ & $\begin{array}{c}\text { Weight } \\
\text { Score } \\
\text { (Nilai } \\
\text { tertimbang) } \\
\end{array}$ & Keterangan \\
\hline Lingkungan & 0,09 & 3 & 0,27 & $\begin{array}{l}\text { Kecamatan Tampan } \\
\text { sebagai daerah pusat } \\
\text { pendidikan terdapat } \\
\text { banyak sekolah, lembaga } \\
\text { pendidikan dan dua } \\
\text { universitas negeri terbesar } \\
\text { di Provinsi Riau yaitu } \\
\text { UNRI dan UIN SUSKA } \\
\text { Riau }\end{array}$ \\
\hline $\begin{array}{l}\text { Pertumbuhan } \\
\text { lapangan } \\
\text { usaha baru }\end{array}$ & 0,08 & 3 & 0.24 & $\begin{array}{l}\text { Di tahun } 2018 \text {, } \\
\text { diprediksikan tenaga } \\
\text { kerja akan berjumlah } \\
\text { sekitar } 124,4 \text { juta dengan } \\
\text { komposisi } 49,7 \text { juta tenaga } \\
\text { kerja penerima upah dan } \\
74,7 \text { juta tenaga kerja } \\
\text { bukan penerima upah }\end{array}$ \\
\hline $\begin{array}{l}\text { Kesedian } \\
\text { akses internet }\end{array}$ & 0,07 & 3 & 0.21 & $\begin{array}{l}\text { Akses penggunaan } \\
\text { internet pekanbaru sudah } \\
\text { baik dari waktu kewaktu }\end{array}$ \\
\hline $\begin{array}{l}\text { Legitas } \\
\text { pemerintah }\end{array}$ & 0,20 & 5 & 1.00 & $\begin{array}{l}\text { kebijakan ini dikelurkan } \\
\text { langsung oleh pemerintah } \\
\text { Indonesia melalu Undang- } \\
\text { undang }\end{array}$ \\
\hline Gaya hidup & 0,05 & 3 & 0.15 & $\begin{array}{l}\text { Perubahan pola piker } \\
\text { tentang perencanaan pada } \\
\text { masa depan }\end{array}$ \\
\hline $\begin{array}{l}\text { Jumlah Nilai } \\
\text { Peluang }\end{array}$ & & & 3.22 & \\
\hline \multicolumn{5}{|l|}{$\begin{array}{l}\text { Ancaman } \\
\text { (Threat) }\end{array}$} \\
\hline $\begin{array}{l}\text { Pesaing } \\
\text { didalam } \\
\text { industri }\end{array}$ & 0,10 & 2 & 0,20 & $\begin{array}{l}\text { Keberadaan industri } \\
\text { asuransi dikota Pekanbaru } \\
\text { bisa dikata cukup banyak } \\
\text { baik dengan skala besar } \\
\text { maupun kecil }\end{array}$ \\
\hline $\begin{array}{l}\text { Produk } \\
\text { penganti }\end{array}$ & 0,06 & 2 & 0,12 & $\begin{array}{l}\text { Sedangkan ancaman } \\
\text { produk penganti BPJS } \\
\text { Ketenagakerjaan saat } \\
\text { ini belum ada yang } \\
\text { paling mendekati adalah } \\
\text { menggunakan fasiltas. }\end{array}$ \\
\hline $\begin{array}{l}\text { Stablitas } \\
\text { Ekonomi }\end{array}$ & 0,05 & 2 & 0.10 & $\begin{array}{l}\text { BPJS Milik Pemerntah, } \\
\text { jadi stabilitas ekonomi } \\
\text { Negara sangat } \\
\text { berpengaruh terhadapa } \\
\text { BPJS }\end{array}$ \\
\hline $\begin{array}{l}\text { Jumlah Nilai } \\
\text { Ancaman }\end{array}$ & & & 0.42 & \\
\hline
\end{tabular}


Berdasarkan tabel 2 diatas EFA(Eksternal Faktor Analisis) ditemukan bahwa faktor yang paling berpengaruh terhadap BPJS ketenagakerjaan adalah peran pemerintah dengan nilai 1.00 karena BPJS Milik Pemerntah, jadi stabilitas ekonomi Negara sangat berpengaruh terhadapa BPJS serta pemerintah memiliki hak untuk membuat peraturan dan undang-undang. Sedangkan faktor yang lain yang mempengaruhi dari sisi eksternal BPJS Ketenagakerjaan adalah stabiltas ekonomi dengan nilai 0.95 alasan adalah Produk Domestik Regional Bruto. (PDRB) atas dasar harga berlaku triwulan III/2016 mencapai Rp172,82 triliun tumbuh 3.40 persen ini bertanda keadaan ekonomi di pekanbaru diposisi baik dan stabil. ini.
Selanjutnya adalah dari sisi ancaman yang paling berpengaruh adalah datang dari pesaing di sesama industry dengan nilai 0.20 . Berdasarakan data-data diatas dapat disimpulkan bahwa nilai eksternal faktor analisi BPJS Ketenagakerjaan untuk pelaung berjumlah 3.22 sedangkan untuk ancaman mendapatakan nilai 0.42 .

Selanjutlah selesai dengan analisis eksternal dari BPJS ketenagakerjaan maka tahapan selanjutnya adalah akan dilakukan penghitungan bobot dari sisi internal BPJS ketenagakerjaan dengan menggunakan IFA (Internal Faktor Analisis) tujuannya dalah untuk melihat kekuatan dan kelemahan dari BPJS Ketenagakerjaan lihat tabel 3 dibawah

Tabel 3. Internal Faktor Analisis: BPJS Ketenagakerjaan

\begin{tabular}{|c|c|c|c|c|}
\hline $\begin{array}{l}\text { Internal } \\
\text { Factor } \\
\text { (Faktor } \\
\text { Internal) }\end{array}$ & $\begin{array}{l}\text { Weight } \\
\text { (Bobot) }\end{array}$ & $\begin{array}{l}\text { Rating } \\
\text { (Nilai) }\end{array}$ & $\begin{array}{l}\text { Weight } \\
\text { Score } \\
\text { (Nilai } \\
\text { Timbang) }\end{array}$ & Keterangan \\
\hline \multicolumn{5}{|l|}{$\begin{array}{l}\text { Kekuatan } \\
\text { (Strenght) }\end{array}$} \\
\hline Modal & 0.12 & 5 & 0.60 & $\begin{array}{l}\text { Aset Tetap yang terdiri } \\
\text { dari Tanah, Bangunan, } \\
\text { Kendaraan Dinas, } \\
\text { Peralatan Kantor } \\
\text { Komputer Peralatan } \\
\text { lain, dan Akses Dalam } \\
\text { Konstruksi }\end{array}$ \\
\hline $\begin{array}{l}\text { Saluran } \\
\text { Distribusi }\end{array}$ & 0.10 & 4 & 0.40 & $\begin{array}{l}\text { BPJS Ketenagakerjaan } \\
\text { memiliki } 121 \text { Kantor } \\
\text { Cabang dan } 53 \text { Kantor } \\
\text { Cabang Perintis }\end{array}$ \\
\hline $\begin{array}{l}\text { Sistem } \\
\text { Informasi }\end{array}$ & 0.08 & 3 & 0.24 & $\begin{array}{l}\text { Memiliki Electronic } \\
\text { Payment System } \\
\text { (E-Payment System/EPS) }\end{array}$ \\
\hline $\begin{array}{l}\text { Sumber daya } \\
\text { Manusia }\end{array}$ & 0.09 & 3 & 0.27 & $\begin{array}{l}\text { Beberapa variabel SDM } \\
\text { telah cukup kompetitif } \\
\text { seperti grading dan } \\
\text { kompensasi. }\end{array}$ \\
\hline $\begin{array}{l}\text { Peran } \\
\text { Pemerintah }\end{array}$ & 0.25 & 5 & 1.25 & $\begin{array}{l}\text { Sebagai pembuat undang- } \\
\text { undang dan kebijakan } \\
\text { yang mengigat. }\end{array}$ \\
\hline Promosi & 0.05 & 4 & 0.20 & $\begin{array}{l}\text { Mengunakan promosi } \\
\text { melalui media online } \\
\text { maupun offline, } \\
\text { elektronik maupun cetak }\end{array}$ \\
\hline
\end{tabular}




\begin{tabular}{|c|c|c|c|c|}
\hline $\begin{array}{c}\text { Internal } \\
\text { Factor } \\
\text { (Faktor } \\
\text { Internal) } \\
\end{array}$ & $\begin{array}{l}\text { Weight } \\
\text { (Bobot) }\end{array}$ & $\begin{array}{l}\text { Rating } \\
\text { (Nilai) }\end{array}$ & $\begin{array}{l}\text { Weight } \\
\text { Score } \\
\text { (Nilai } \\
\text { Timbang) }\end{array}$ & Keterangan \\
\hline $\begin{array}{l}\text { Budaya } \\
\text { perusahaan }\end{array}$ & 0.04 & 3 & 0.12 & $\begin{array}{l}\text { Memiliki visi dan misi } \\
\text { serta nilai perusahaan } \\
\text { yang bagus }\end{array}$ \\
\hline $\begin{array}{l}\text { Jumlah Nilai } \\
\text { Kekuatan }\end{array}$ & & & 3.08 & \\
\hline \multicolumn{5}{|l|}{$\begin{array}{l}\text { Kelemahan } \\
\text { (Weakness) }\end{array}$} \\
\hline Positioning & 0.09 & 4 & 0.36 & $\begin{array}{l}\text { Masyarakat masih } \\
\text { binggung membedakan } \\
\text { BPJS Kesehatan dengan } \\
\text { BPJS Ketenagakerjaan }\end{array}$ \\
\hline Branding & 0.07 & 3 & 0.21 & $\begin{array}{l}\text { Branding baik masih } \\
\text { lemah di benak } \\
\text { masyarakat }\end{array}$ \\
\hline Pelayanan & 0.10 & 4 & 0.40 & $\begin{array}{l}\text { Masih ada kekurangan } \\
\text { pelayanan dan keluhaan } \\
\text { dari masyarakat. }\end{array}$ \\
\hline $\begin{array}{l}\text { Jumlah Nilai } \\
\text { Kelemahan }\end{array}$ & & & 0.97 & \\
\hline
\end{tabular}

Sumber: (Data Olahan, 2016).

Berdasarakan tabel 2 diatas faktor yang paling berpengaruh terhdap BPJS Ketenagakerjan dari sisi internal BPJS ketenagakerjaan adalah modal dengan nilai 0.60 alasanya adalah kenapa faktor ini penting adalah aset tetap yang terdiri dari tanah, bangunan, kendaraan dinas peralatan kantor komputer peralatan lain dan akses dalam konstruksi serta mendapatkan sumber pendaan dari pemerintah pusat. faktor lain yang memiliki pengaruh terhadap BPJS Ketengakerjaan yang adalah peran permintah pusat dengan nilai 1.25 hal ini disebabkan oleh sebagai pembuat undang-undang dan kebijakan yang mengikat baik itu perusahaan, masyarakat umum dan BPJS Ketengakaerjaan itu sendiri untuk patuh dan taat terhadapa undangan-undang yang telah pemerintah buat.. selanjutnya adalah faktor internal dari sisi kelemahan BPJS Ketengakerjan adalah pada positioning dengan nilai 0.36 dan pelayanan dengan nilai 0.40 hal ini disebabkan oleh BPJS Ketenagakerjaan masih baru beridiri dan perlu ada banyak pelatihan dan untuk menignkatkan pelayanan kepada nasabah.
Setelah dilakukan pemobobotan dari masing-masing dari faktor EFA dan IFA selanjutnya akan dilakukan penghitungan selisih dari lingkungn internal dan eksternal tujuan dari penghitungan ini adalah untuk melihat posisi strategis (Pantano \& Genovese, 2016), (Suliyanto, siti Zulaikha Wulandari, 2010)dari BPJS Ketenagakerjaan dengan mengunakan SWOT-8K lihat tabel 4 dibawah ini.

\begin{tabular}{lc}
\multicolumn{2}{c}{ Tabel 4. Selisih Internal\&Eksternal (Matrik GE) } \\
\hline $\begin{array}{lc}\text { Eksternal BPJS Ketenagakerjaan } \\
\text { Cab panam }\end{array}$ & Nilai selisih \\
\hline Peluang & 3.22 \\
Ancaman & 0.42 \\
Selisih & 2.80 \\
Internal BPJS Ketengakerjaan Cab & \\
Panam & \\
Kekuatan & 3.08 \\
Kelemahan & 0.97 \\
Selisih & 2.98 \\
\hline \multicolumn{2}{c}{ Sumber; (Data olahan, 2016) }
\end{tabular}

Berdasarkan tabel 4 diatas ditetemukan nilai selisih yang positi dimana nilai selisih 
untuk ancaman dan peluang diperoleh hasil 2.80 sedangkan selisih dari kekuatan dan kelemahan diperoleh hasil 2.98 setelah diketahui dari masing-masing selisih maka dilakukan pengurangan sehingga ditemukan hasi selisih sebesar 2.80 dan 2.98 dari nilai tersebut ditemukan posisi BPJS Ketenagakerjaan di posisi tumbuh dengan stabil untuk lebih jelas lihat gambar 3 dibawah ini

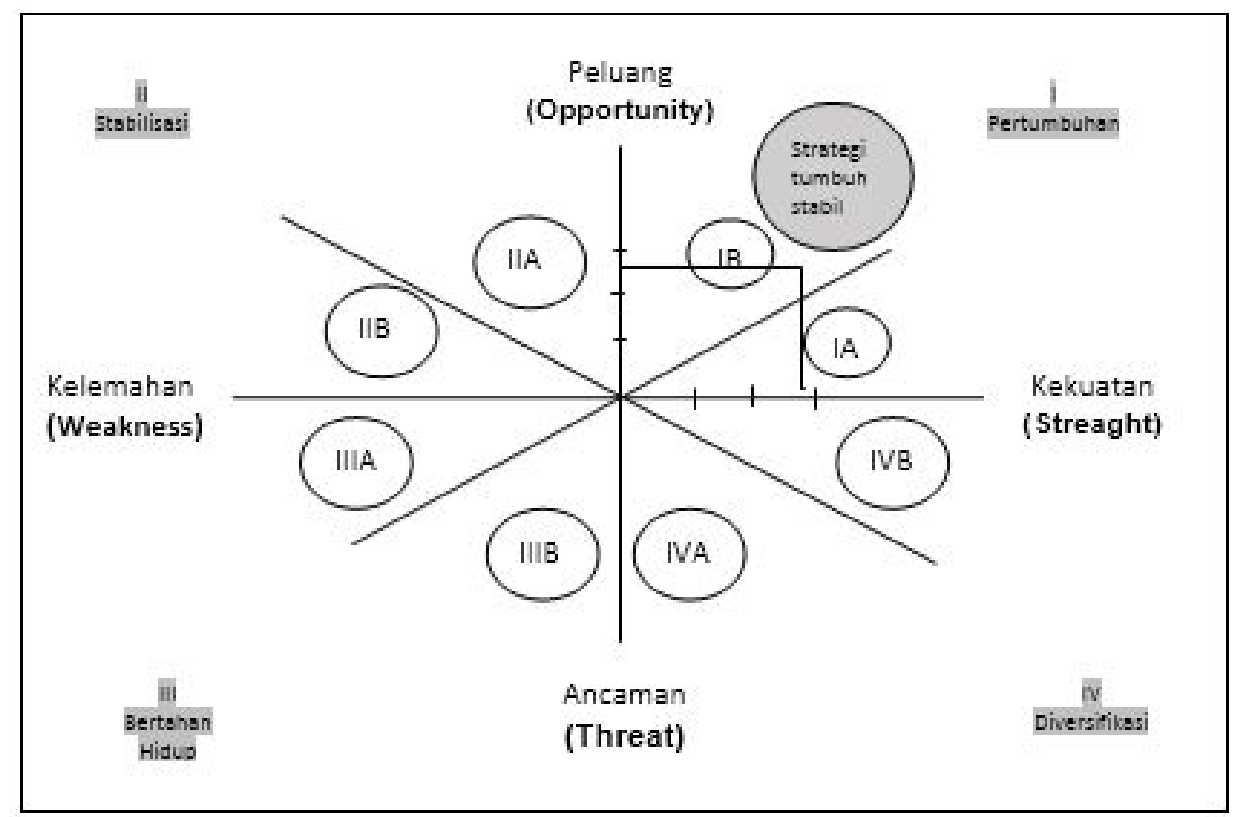

Gambar3. Matrik SWOT-8K BPJS Ketenagakerjaan

Sumber: (Data olahan, 2016)

Berdasarkan gambar SWOT-8K diatas ditemukan bahwa BPJS Ketenagakerjaan berada pada kuadran IB dengan nilai 2.80 pada sumbuh peluang dan ancamanan sedangkan 2.98 pada sumbu kekuatan dan kelemahan ini berarti BPJS Ketenagakerjaan dapat menyusun strategi tumbuh dengan stabil dan pelanpelan tidak terlalu agresif. Setelah dilakukan dan ditemukan posisi strategis dari BPJS ketenagakerjaan tahapan selanjutnya adalah akan dilakukan penyusunan dan perumusan strategi dengan mengunakan matrik TWOS untuk lebih jelas lihat tabel 5 dibawah ini. Matrik TWOS merupakan varian untuk alat analisis bisnis klasik (Davies, John, \& Thomas, 2014). Sedangkan menurut (Pereira, Salazar, Abelha, \& Machado, 2013) TWOS merupakan suatu kegiatan untuk mencampur/ formula dari kekuatan dengan perluang (SO), kelemahan dengan peluang (WO), kekuatan dengan ancaman (ST) dan Kelemahan dengan ancaman (WT). 
Tabel 5. Matrik TWOS BPJS Ketenagakerjaan

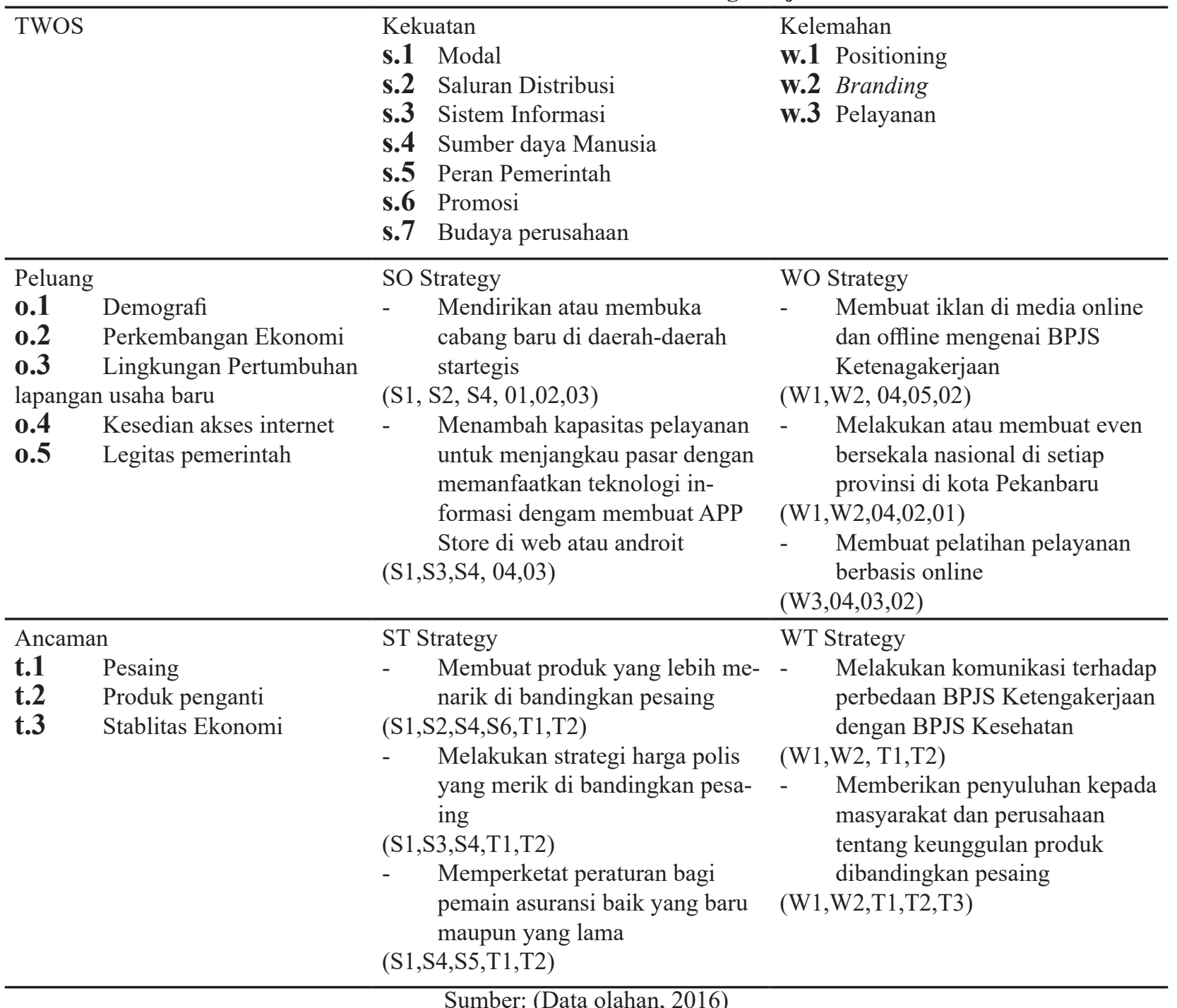

Berdasarkan tabel 5 diatas tetang matrik TWOS dapat dijelaskan bahwa ada beberapa pilihan strategi yang bisa dipilih untuk digunakan untuk tumbuh dan bersaing di industriasuransi di kota Pekanbaru diantara strategi yang bisa digunakan adalah (1) Mendirikan atau membuka cabang baru di daerah-daerah startegis, (2) Menambah kapasitas pelayanan untuk menjangkau pasar dengan memanfaatkan teknologiinformasi dengam membuat APP Store, web atau androit dan (3) Melakukan penetrasi pasar dan pengembangan pasar ke seluruh kabupaten di Provinsi Riau khususnya kota Pekanbaru.
Selanjutnya adalah tahapan pemilihan alternative strategi yang dapat dipilih BPJS Ketenagakerjaan untuk dapat bersaing dan tumbuh dengan mengunakan teknik analisis Matrik QSPM yang merupakan aplikasi untuk mengproritaskan faktor-faktor sebelumnya (Abya, Khalili, dan Ebrahimi, 2015) dan menemilih strategi yang paling tepat dibandingkan strategi-strategi yang lain (Shiehbeiki dkk., 2014) dan merupak alat yang semperuna untuk memilih strategi (Gupta, 2015)untuk lebih jelas lihat tabel 6 dibawah ini. 
Tabel 5. Matrik QSPM BPJS Ketenagakerjaan

\begin{tabular}{|c|c|c|c|c|c|c|c|}
\hline \multirow{3}{*}{$\begin{array}{c}\text { Key } \\
\text { Faktor }\end{array}$} & \multicolumn{7}{|c|}{ ALTERNATIF STRATEGI } \\
\hline & \multirow{2}{*}{ Bobot } & \multicolumn{2}{|c|}{$\begin{array}{c}\text { Competitive } \\
\text { Strategy } \\
\end{array}$} & \multicolumn{2}{|c|}{$\begin{array}{l}\text { Growth } \\
\text { Strategy }\end{array}$} & \multicolumn{2}{|c|}{ Stabilization } \\
\hline & & $\mathbf{A S}$ & TAS & AS & TAS & AS & TAS \\
\hline \multicolumn{8}{|l|}{ PELUANG } \\
\hline Demografi & 0.12 & 3 & 0.36 & 3 & 0.36 & 2 & 0.16 \\
\hline $\begin{array}{l}\text { Perkem- } \\
\text { bangan } \\
\text { Ekonomi }\end{array}$ & 0.10 & 3 & 0.30 & 2 & 0.20 & 3 & 0.30 \\
\hline Lingkungan & 0.08 & 2 & 0.16 & 2 & 0.16 & 2 & 0.16 \\
\hline $\begin{array}{l}\text { Pertumbu- } \\
\text { han lapan- } \\
\text { gan usaha } \\
\text { baru }\end{array}$ & 0.09 & 3 & 0.27 & 2 & 0.18 & 2 & 0.18 \\
\hline $\begin{array}{l}\text { Kesedian } \\
\text { akses inter- } \\
\text { net }\end{array}$ & 0.25 & 3 & 0.75 & 3 & 0.75 & 2 & 0.50 \\
\hline $\begin{array}{l}\text { Legitas } \\
\text { pemerintah }\end{array}$ & 0.05 & 4 & 0.20 & 4 & 0.20 & 3 & 0.15 \\
\hline Gaya hidup & 0.04 & 3 & 0.12 & 2 & 0.08 & 1 & 0.04 \\
\hline \multicolumn{8}{|l|}{$\begin{array}{l}\text { ANCA- } \\
\text { MAN }\end{array}$} \\
\hline Pesaing & 0,10 & 3 & 0.30 & 4 & 0.40 & 2 & 0.20 \\
\hline $\begin{array}{l}\text { Produk } \\
\text { penganti }\end{array}$ & 0,06 & 1 & 0.06 & 2 & 0.12 & 2 & 0.12 \\
\hline $\begin{array}{l}\text { Stablitas } \\
\text { Ekonomi }\end{array}$ & 0,05 & 2 & 0.10 & 2 & 0.10 & 2 & 0.10 \\
\hline \multicolumn{8}{|l|}{$\begin{array}{l}\text { KEKUA- } \\
\text { TAN }\end{array}$} \\
\hline Modal & 0.12 & 4 & 0.48 & 3 & 0.36 & 2 & 0.24 \\
\hline $\begin{array}{l}\text { Saluran } \\
\text { Distribusi }\end{array}$ & 0.10 & 4 & 0.40 & 2 & 0.20 & 2 & 0.20 \\
\hline $\begin{array}{l}\text { Sistem } \\
\text { Informasi }\end{array}$ & 0.08 & 3 & 0.24 & 2 & 0.16 & 2 & 0.16 \\
\hline $\begin{array}{l}\text { Sumber } \\
\text { daya Ma- } \\
\text { nusia }\end{array}$ & 0.09 & 3 & 0.27 & 3 & 0.21 & 2 & 0.18 \\
\hline $\begin{array}{l}\text { Peran } \\
\text { Pemerintah }\end{array}$ & 0.25 & 4 & 1.00 & 3 & 0.75 & 2 & 0.50 \\
\hline Promosi & 0.05 & 2 & 0.10 & 2 & 0.10 & 2 & 0.10 \\
\hline $\begin{array}{l}\text { Budaya } \\
\text { perusahaan }\end{array}$ & 0.04 & 2 & 0.08 & 2 & 0.08 & 2 & 0.08 \\
\hline \multicolumn{8}{|l|}{$\begin{array}{l}\text { KELEMA- } \\
\text { HAN }\end{array}$} \\
\hline Positioning & 0.09 & 3 & 0.27 & 2 & 0.18 & 2 & 0.18 \\
\hline Branding & 0.07 & 3 & 0.21 & 2 & 0.14 & 2 & 0.14 \\
\hline Pelayanan & 0.10 & 3 & 0.30 & 2 & 0,20 & 2 & 0.20 \\
\hline JUMLAH & & 5.97 & & & 4.73 & & 3.89 \\
\hline
\end{tabular}


Berdasarkantabel4diatas diketahuibahwa nilai QSPM yang paling tinggi di tunjukan pada strategi competitive strategi(strategi bersaing) dengan nilai 5.97 dengan nilai TAS tertinggi pada faktor modal dengan nilai 0.48 . Sedangkan strategi yang lain yang bisa digunakan yaitu strategi tumbuh dengan nilai 4.73 dan strategi stabilisasi dengan nilai 3.89.

\section{KESIMPULAN}

Untuk dapat tumbuh dan bersaing bagi perusahaan baru dengan skala yang besar seperti BPJS Ketenagakerjaan di industry asuransi kota Pekanbaru tentu bukanlah hal yang mudah untuk di jalani dimana sebelum BPJS Ketenagakerjaan berdiri sudah ada perusahaan asuransi yang lain sudah berdiri dan memiliki skala, nama baik dan terkenal dan pangsa pasar yang luas seperti Prudential, Manulife, Axxa mandiri, Jiwaseraya, AIG, Zurich, Tokyo marine, dan lain-lain. Namun untuk tumbuh dan bersaing BPJS Ketenagakerjaan di industry ini BPJS berhasil bersaing dan tumbuh dengan berbagai indikator diantaranya pembukaan cabang diseluruh Indonesia, memberikan pelayanan baik, tingkat kepuasan dari nasabah dilevel menengah karena perlu banyak pelatihan kepada manajemen BPJS Ketenagakerjaan. setelah dilakukan tahapan demi tahapan penyusunan strategi dimulai dari analisis Five Force Porter, EFA,IFA, Matrik GE, SWOT-8K, Matrik TWOS, dan Matrik QSPM maka, disimpulan bahwa posisi strategi BPJS Ketenagakerjaan berada diposisi tumbuh dan memiliki keunggulan bersaing yang langka yang tidak dimiliki oleh perusahaan asuransi lainya yaitu adanya peran pemerintah dalam membuat peraturan dan undang-undang. Adapun kedepan bagi BPJS Ketenagakerjaan yaitu (1) Mendirikan atau membuka cabang baru di daerah-daerah strategis, (2) Menambah kapasitas pelayanan untuk menjangkau pasar dengan memanfaatkan teknologiinformasi dengam membuat APP Store, web atau androit dan (3) Melakukan penetrasi pasar dan pengembangan pasar ke seluruh kabupaten di
Provinsi Riau khususnya kota Pekanbaru.

\section{DAFTAR PUSTAKA}

Abya, H., Khalili, M., \& Ebrahimi, M. (2015). Strategic Planning For Tourism Industry Using Swot And Qspm. Management Science. Retrieved From Http:// Growingscience.Com/Beta/Msl/1881Strategic-Planning-For-TourismIndustry-Using-Swot-And-Qspm.Html

Ang, H. (2014). Model Supply Chain Management Dan Perancangan Aplikasi E-Scm Pada Pt Indofood Sukses Makmur Tbk Bogasari Flour Mills Division. Journal T He Winners, 15(1), 72-84.

Ayub, A., Razzaq, A., Aslam, M. S., \& Iftekhar, H. (2013). A Conceptual Framework On Evaluating Swot Analysis As The Mediator In Strategic Marketing Planning Through Marketing Intelligence. Business And ..., 2(1), 9198. Retrieved FromHttp://Www.Ejbss. Com/Data/Sites/1/Vol2nol april2013/ Ejbss-Vol-2-No-1_Apri12013. Pdf\#Page $=150$

Bell, G. G., \& Rochford, L. (2016). Rediscovering Swot's Integrative Nature: A New Understanding Of An Old Framework. International Journal Of Management Education, 14(3), 310-326. Https://Doi.Org/10.1016/J. Ijme.2016.06.003

Bpjs Ketenagakerjaan. (2015). Kualitas Pelayanan Badan Penyelenggara Jaminan Sosial (Bpjs) Ketenagakerjaan, 97-111.

Bull, J.W.; Jobstvogt, N.; Böhnke-Henrichs, A.; Mascarenhas, A.; Sitas, N.; Baulcomb, C.; Lambini, C.K.; Rawlins, M.; Baral, H.; Zähringer, J.; Carter-Silk, E.; Balzan, M.V.; Kenter, J.O.; Häyhä, T.; Petz, K.; Koss, R. (2016). Strengths, Weaknesses, Opportunities And Threats: A Swot Analysis Of The Ecosystem 
Services Framework. Ecosystem Services,Environmental Policy,Surveys, 17(February), 129-140. Https://Doi. Org/Http://Dx.Doi.Org/10.1016/J. Ecoser.2015.11.012

David, F. R. D. \& F. R. (2014). Strategic Management: A Competitive Advantage Approach, Concepts\& Cases (15th Editi). Pearson.

Davies, A., John, E., \& Thomas, A. (2014). Corporate Strategy Development Via Numerical Situation Analysis. Benchmarking: An International. Retrieved From Http://Www. Emeraldinsight.Com/Doi/Abs/10.1108/ Bij-05-2012-0033

Dobbs, M. E. (2014). Guidelines For Applying Porter's Five Forces Framework: A Set Of Industry Analysis Templates. Competitiveness Review, 24(1), 32 45. Https://Doi.Org/Http://Dx.Doi. Org/10.1108/Cr-06-2013-0059

Elyati Henny. (2012). Prudential Buka Cabang Keempat - Riaupos.Co. Retrieved January 23, 2017, From Http://Www. Riaupos.Co/16990-Berita-PrudentialBuka-Cabang-Keempat-.Html\#. Wivt8nj95ww

Gupta, M. (2015). Strategy Formulation For Performance Improvement Of Indian Corrugated Industry: An Application Of Swot Analysis And Qspm Matrix. Journal Of Applied Packaging Research. Retrieved From Http://Scholarworks.Rit.Edu/Japr/Vol7/ Iss 3/3/?Utm_Source=Scholarworks. Rit.Edu\%2fjapr\%2fvo17\%2fiss 3 $\% 2 \mathrm{f} 3 \&$ Utm_Medium=Pdf\&Utm Campaign $=$ Pdfcoverpages

Hunger David, W. L. T. (2013). Manajemen Strategis. Yogyakarta: Adi.

Hunt, S. D., \& Hunt, S. D. (2014). Teaching Dynamic Competition In Marketing Teaching Dynamic Competition In
Marketing. Atlantic Marketing Journal, 3(2), 80-93.

Jeyaraj, K. L., Muralidharan, C., Senthilvelan, T., \& Deshmukh, S. G. (2012). Application Of Swot And Principal Component Analysis In A Textile Company - A Case Study. International Journal Of Engineering Research And Development, 1(9), 46-54.

Lee, H., Kim, M. S., \& Park, Y. (2012). An Analytic Network Process Approach To Operationalization Of Five Forces Model. Applied Mathematical Modelling, 36(4), 1783-1795. Https:// Doi.Org/10.1016/J.Apm.2011.09.012

Mirzakhani, M., Parsaamal, E., \& Golzar, A. (2014). Strategy Formulation With Swot Matrix: A Case Study Of An Iranian Company. Global Business \& Management Research, 6(2), 150-168. Retrieved From Http://Www.Systems. Wsu.Edu/Scripts/Wsuall.Pl?Url=Http:// Search.Ebscohost.Com/Login.Aspx?Di rect $=$ True $\& \mathrm{Db}=\mathrm{B}$ th $\& \mathrm{An}=98850616 \& \mathrm{~S}$ ite $=$ Bsi-Live

Morgan, N. A. (2012). Marketing And Business Performance. J. Of The Acad. Mark. Sci., 40(July 2011), 102-119. Https://Doi.Org/10.1007/S11747-0110279-9

Muhammad, S. (2013). "Manajemen Strategik Konsep Dan Alat Analisi.”. Yogyakarta: Upp Stim Ykpn.

Nofrizal. (2016). Analisis Strategi Pemasaran Bmt Al Ittihad Rumbai Dalam Memperluas Pasar. Pekbis Jurnal, 8(3), 228-240. Retrieved From Http:// Ejournal.Unri.Ac.Id/Index.Php/Jpeb/ Article/View/3637/3537

Pantano, K., \& Genovese, J. (2016). The Effect Of Internally Versus Externally Focused Balance Training On Mindfulness. International Journal Of. Retrieved From Http://Digitalcommons. 
C i is. Edu/Cgi/View content. Cgi? Article $=1477 \&$ Context $=$ Ijts Transpersonalstudies

Pereira, R., Salazar, M., Abelha, A., \& Machado, J. (2013). Swot Analysis Of A Portuguese Electronic Health Record. E-Business, E-Services And E. Retrieved From Http : // Link.Springer. Com / Chapter / 10.1007 / 978-3-64237437-1_14

Porter, M. E. (2011). Competitive Advantage Of Nations: Creating And Sustaining Superior Performance. Simon And Schuster.

Sabol, A., Šander, M., \& Fučkan, Đ. (2013). The Concept Of Industry Life Cycle And Development Of Business Strategies. Active Citizenship By Knowlegde Management And Learning, 635-642.

Safiullin, M. R., Samigullin, I. G., \& Safiullin, L. N. (2013). Model Of Management Of Competitiveness of A MachineBuilding Complex. World Applied Sciences Journal, 27(13), 212-216. Https://Doi.Org/10.5829/Idosi. Wasj.2013.27.Emf.44

Saputro, A. S., Hidayat, K., \& Yulianto, E. (2016). Perencanaan Strategi Pemasaran Paket Data Kampus Dalam Persaingan Di Bidang Paket Data Internet (Studi Kasus Pada Pt. Telkomsel Cabang Malang). Jurnal Administrasi Bisnis, 36(1), 163-169.

Sevkli, M., Oztekin, A., Uysal, O., Torlak, G., Turkyilmaz, A., \& Delen, D. (2012). Development Of A Fuzzy Anp Based Swot Analysis For The Airline
Industry In Turkey. Expert Systems With Applications, 39(1), 14-24. Https://Doi. Org/10.1016/J.Eswa.2011.06.047

Shiehbeiki, S., Abbaspour, M., \& Monavari, S. (2014). Public Participation Role In Sustainable Urban Management By Quantitative Strategic Planning Matrix (Qspm). International Journal Of. Retrieved From Http://Ijer.Ut.Ac.Ir/Article_823_ A6dbd41bba0dfc4f5a5579dff4e413ea. Pdf

Suliyanto, Siti Zulaikha Wulandari, W. N. (2010). Competitive Strategy Model For Purbalingga Batik. Economic Journal Of Emerging Markets, 2(2), 170-185.

Swaonline. (2013). Strategi Manulife Indonesia Kembangkan Agen Tahun 2013 | Swa.Co.Id. Retrieved December 8, 2016, From Http://Swa.Co.Id/Swa/ Trends/Management/Strategi-ManulifeIndonesia-Kembangkan-AgenTahun-2013

Tewari, G. C. (2016). A Swot Analysis Of Serva Shiksha Abhiyan In Uttar Pradesh. Gjra - Global Journal For Research Analysis, 5(9), 255-257.

Wheelen. Thomas L, H. J. D. (2016). Strategic Management And Business Policy Toward Global Sustainability. (13th Edition, Ed.). Pearson.

Wheelen Thomas L. , Hunger J.David, H. A. N. (2014). Strategic Management And Business Policy: Globalization, Innovation And Sustainablitity. (14th Edition, Ed.). Pearson. 